\title{
LEARNING THE LESSONS
}

OF MODERN WAR 
This page intentionally left blank 


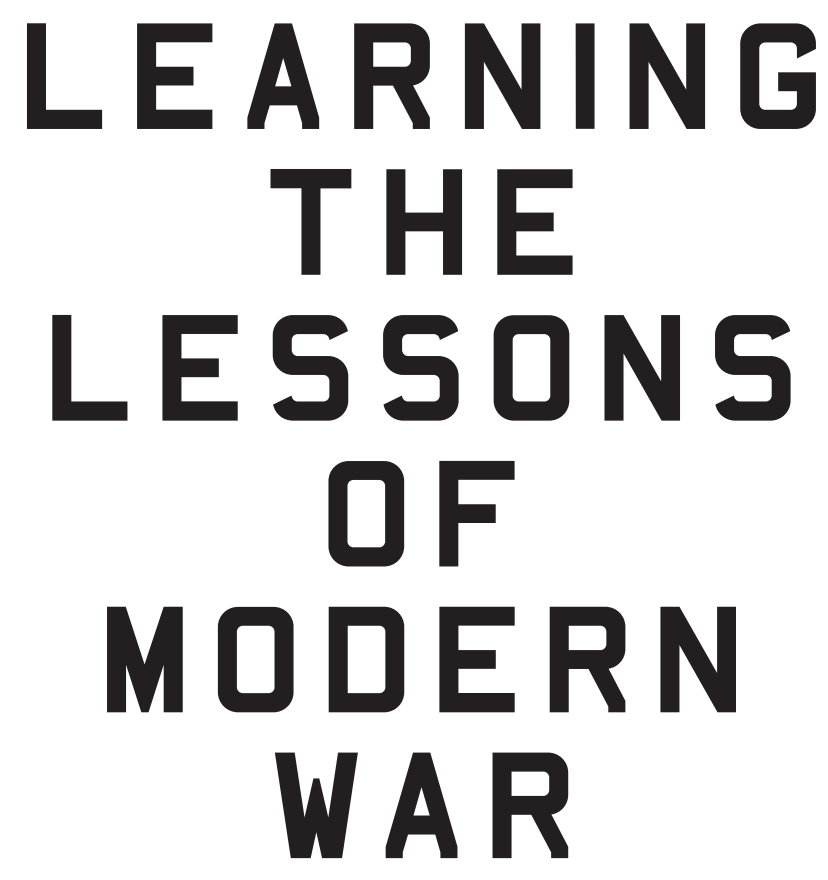

Edited by

Thomas G. Mahnken

STANFORD UNIVERSITY PRESS

Stanford, California 
STANFORD UNIVERSITY PRESS

Stanford, California

(C) 2020 by the Board of Trustees of the Leland Stanford Junior University. All rights reserved.

No part of this book may be reproduced or transmitted in any form or by any means, electronic or mechanical, including photocopying and recording, or in any information storage or retrieval system without the prior written permission of Stanford University Press.

Printed in the United States of America on acid-free, archival-quality paper Library of Congress Cataloging-in-Publication Data

Names: Mahnken, Thomas G., I965- editor.

Title: Learning the lessons of modern war / edited by Thomas G. Mahnken.

Description: Stanford, California : Stanford University Press, 2020. I Includes bibliographical references and index.

Identifiers: LCCN 2020004559 (print) I LCCN 2020004560 (ebook) I ISBN 978I 5036I 2266 (cloth) I ISBN 978I 5036I250I (paperback) I ISBN 978 I 5036 I 25 I 8 (ebook)

Subjects: LCSH: Military art and science-History-2 Ist century. I Military history, Modern-2 Ist century. I Afghan War, 200I- I Iraq War, 2003-20II.

Classification: LCC U42.5 .L43 2020 (print) I LCC U42.5 (ebook) I DDC $355 / .02-\mathrm{dc} 23$

LC record available at https://lccn.loc.gov/2020004559

LC ebook record available at https://lccn.loc.gov/2020004560

Cover design: Kevin Barrett Kane

Cover photograph: Xenia8oo 